Dirk Hoerder

\title{
Migration Research in Global Perspective: Recent Developments
}

Migration history was, for long, Atlanto-centric and framed by traditional nation-state discourse: European migrants moved from a nation to an ethnic enclave, e.g. from Italy to a Little Italy in some US city. The emigration countries' nationalist historians would, usually, not mention emigrants - they were no longer part of the nation. (These historians would have had to question national identity constructs, had they taken into account the millions who left...). US scholars began their stories at Ellis Island because, not familiar with migrants' language of birth, they could not study socialization in the culture of origin. They did not even care to look at Angel Island, the entry gate or, more often, detention center for migrants from Asian cultures. They called the border to Mexico a "backdoor," a kind of servants' entry for "brown" men and women. They assumed that immigrants carried some kind of "cultural baggage," to be dropped as soon as possible. The paradigmatic frame of interpretation was the so-called Chicago School of Sociology's notion of "dislocation" and, perhaps, dysfunctionality, as well as Harvard's Oscar Handlin's notion of "uprootedness."

Since the 1970s, the field has come a long way and migration history became interdisciplinary migration research or migration studies. ${ }^{1}$ A brief retrospect will connect the 1970 s developments to

\footnotetext{
${ }^{1}$ For an outline of the field see Christiane Harzig / Dirk Hoerder / Donna Gabaccia, What is Migration History?, Cambridge 2009, Chapter 2. A major anthology on migration theory is Jan Lucassen and Leo Lucassen (eds.), Migration, Migration History, History: Old Paradigms and New Perspectives, Bern 1997 (second, revised edition: 1999). See also Caroline B. Brettell / James F. Hollifield (eds.), Migration Theory: Talking Across Disciplines, London 1999 (revised edition: 2008)
} 
Dirk Hoerder

earlier approaches marginalized in scholars' memory. The dislocation-uprootedness paradigm fit the preconceptions of the public and of politicians, but also of scholars socialized in such discourses. Researchers, however, could have recognized differentiated earlier approaches. Research conducted at Columbia University from the 1890 s to the 1930s and inspired by Franz Boas explicated the complexity of European, African, African-Caribbean, and Mexican immigration - but Columbia's scholars were of Jewish faith, women, African-Americans, and Mexicans. ${ }^{2}$ Out of it came - concerning transatlantic migrations - Caroline Ware's detailed social history of Greenwich Village, New York. This path-breaking work was not even cited by the Chicago and Harvard men. ${ }^{3}$ Furthermore, the Chicago men's sociology had been preceded by the Chicago Women's School of Sociology, whose results were subsequently downgraded to data collection and applied social work. ${ }^{4}$ In the 1930 s and 1940s, sophisticated studies of acculturation and métissage analyzed the creation of the transcultural Brazilian, Cuban, and Canadian societies. The gatekeeper-scholars in the Atlantic world's centers of knowledge production closed their minds to such authors. ${ }^{5}$ Empirical and theoretical work done from the 1880 s to the 1910 s by Ravenstein in England and von Randow and Caro in the Habsburg Empire was also hardly cited - the German Max Weber, in contrast, pronounced Poles in the Reich to be inferior. As regards the world outside the Atlantic's realm, early works on Asian migrations were published by Persia Campbell, Ta Chen, and Hugh Tinker, but they

and Caroline B. Brettell, 'The Individual / Agent and Culture / Structure in the History of the Social Sciences', Social Science History, 26 (2002), pp. 429-445.

${ }^{2}$ For a detailed study, see Dirk Hoerder, 'A Genuine Respect for the People': The Columbia University Scholars' Transcultural Approach to Migrants (forthcoming).

${ }^{3}$ Caroline F. Ware, Greenwich Village, 1920-1930: A Comment on American Civilization in the Post-War Years, Boston 1935.

${ }^{4}$ Patricia Madoo Lengermann / Jill Niebrugge-Brantley, The Women Founders: Sociology and Social Theory, New York 1998.

${ }^{5}$ Works by Gilberto Freyre, Fernando Ortiz, and Helen MacGill Hughes and Everett Hughes. 
Migration Research in Global Perspective: Recent Developments

were also marginalized; ${ }^{6}$ studies on the forced migrations of African slaves were relegated to the separate subfield of studies on slavery. Scholars who began to re-conceptualize approaches to migration in the 1970s and 1980s were, at first, prisoners of the provincial view that took the (white) European and the Atlantic segments of the world to be the norm.

From the 1970s, detailed community studies of migrants, from the 1980s, vastly increased attention to other parts of the globe, whether in macro-regional or world-history perspectives, and from the 1990s, the study of global interactions have changed the field. In this brief survey, terminologies and conceptualizations - including agency and gender - will be addressed first and macro-regional migration systems and social spaces of migration second. Next, some of the many recent publications will be mentioned. Reflections on changes in global migrations at the beginning of the 21st century and, thus, changing research needs, especially the shift to the BRIC countries (Brazil, Russia, India, China), as well as the migratory consequences of the global crisis, will conclude this essay.

\section{Terminologies and Conceptualizations: Forced and Free Migration, Gender and Agency}

In global approaches to migration, traditional terminology juxtaposed emigration to immigration and, occasionally, added "coolie" migrations and other mobilities. Misleading naming of social phenomena prevents questions being asked, hypotheses being formulated, and even data being collected. As regards data, the label "immigration" country for the US prevented collection of information on circular and return migration - around 1900 one third of the

\footnotetext{
${ }^{6}$ Persia C. Campbell, Chinese Coolie Emigration to Countries within the British Empire, London 1923; Ta Chen (for the US Department of Labor), Chinese Migrations With Special Reference to Labor Conditions, Washington 1923; Hugh Tinker, A New System of Slavery: The Export of Indian Labour Overseas 1830-1920, London 1974
} 
Dirk Hoerder

"immigrants" returned to Europe, were temporary migrants or "guest workers," to use another problem-laden term. The gender ideology-based assumption that women were "associational" to or "dependent" upon men prevented collection of data on women 40 percent of the transatlantic migrants were female. Slaves, "coolies" and forced laborers under fascism, Stalinism, apartheid or other regimes, not having migrated of their own will, were considered "passive" and slotted into different research approaches and sub-disciplines. Imperial personnel in colonized regions, on the other hand, such as powerful agents of the Roman, British, or Chinese empires, were considered stationary rulers, although all of them were migrants.

"Migration," as a neutral term, comprises single and multiple moves; uni- and multi-directional ones; circular, return, reverse, and stepwise moves; seasonal, temporary, multi-annual, and permanent ones. The latter may be unintentionally permanent - migrants who always planned to return but never did - or involuntarily permanent - return was desired but not possible. Inclusion of migrant agency - in structural frames and economic options or constraints - differentiates impersonal "flows" or "streams" of migrants and reveals the complexities of mobility. One attempt to arrive at a standardized definition of a migrant posits that a person must have lived away from his/her previous place of residence (not: place of birth) for a year or more. But this time-frame is no more than a heuristic device for data collection. Travels in the past, e.g. across the Tsarist Empire, may have taken years and thus, like migration, may have had acculturating effects; merchant families in the early modern Mediterranean and 19th-century Southeast Asian Chinese diaspora have been said to be temporary migrants, although they might stay for two or more generations.

When the forced migrations to which African slaves, Asian indentured laborers, Ostarbeiter, and others were subjected became part of migration research, the juxtaposition of free and forced seemed self-evident. But these categories involved insidious connotations and imposed restraints on analyses. First, slaves and oth- 
Migration Research in Global Perspective: Recent Developments

er forced worker-migrants were considered passive - they "naturally" cannot become masters (or mistresses) of their own lives; "coolies," in the same frame of reference, were said to be depraved and in need of control. Thus a forced labor regime, the systemic passivizing of a labor force by exploiters, was changed terminologically and implicitly into a character trait of the (black, brown, yellow) victims of the system. In contrast, free migrants - implicitly European and white - where assumed to be active and, given their ascribed capabilities, of superior culture. This passive-active juxtaposition made racialization part of migration discourses and research. Second, as to the "free" white migrants: European men and women left economies that did not provide for subsistence as well as hierarchical societies that precluded betterment for the lower classes. From the point of view of life projects or even survival, they were disaster zones. Thus men and women left under extreme constraints; they were "self-willed" only to the degree that a decision could be made as to who would leave. In addition, until the 1820 s, more than half of transatlantic migrants were too poor to pay their passage and had to indenture themselves, i.e. bind themselves to someone who paid their passage. Analyses require inclusion of the structural constraints of Europe's societies, as well as of the agency of enslaved men and women who rebuilt their lives under conditions of bondage. All of these newcomers built the societies of the Americas and sustained production in the global plantation belt. The degree of choice in departure - low, for example, for refugees - impacts the options to reconstruct lives in a society of arrival. Migrants who decide upon departure and choose a destination can prepare; forced laborers and refugees are cast about by impersonal warfare, expulsion, and labor regimes. They can neither prepare nor pro-act but have to re-act to power impositions and circumstances. ${ }^{7}$

${ }^{7}$ This is discussed in more detail in Harzig et al., What is Migration History? (as cited in note 1$)$. 
Dirk Hoerder

As in much of history written by men, migrating women were subsumed under men, were made invisible or, as one scholar called it, were symbolically annihilated. Data on women's migrations have always been available but require critical reflection on sources. Statistics on crossings of inter-national borders were collected by nation-state apparatuses, a gendered construction in itself: male officials socialized in gendered societies counted men and labeled women and children as "dependents." However, "vital records" in migrants' local or regional communities of departure contain information about women and, for that matter, about family migration and departure of children. ${ }^{8}$ Employers of migrant workers, self-willed or bound, specified whether they needed a reservoir of male or female workers or both and whether they hired child labor. Women often developed their own migration routes and patterns of sequential migration. Globally, but depending on culture, labor markets, and duration of a migration flow, women accounted for one half of all migrants in the 19th-century intra-European migrations, ${ }^{9}$ and in transatlantic ones since the 1930s. Before the 1930s, women accounted for about 40 percent of departures from Europe, in migrations of South Asian indentured workers, 1830s to 1930s, for 25 to 33 or more percent. Only in South Chinese migrations was the share of women small. ${ }^{10}$ The high visibility of women migrants since the 1990s has led to public debates and scholarly pro-

${ }^{8}$ This has been pointed out by Sylvia Hahn, Migration - Arbeit - Geschlecht. Arbeitsmigration in Mitteleuropa vom 17. bis zum Beginn des 20. Jahrhunderts, Göttingen 2008, pp. 18, 32-33, 157-244.

${ }^{9}$ Marlou Schrover, 'Feminization and Problematization of Migration: Europe in the Nineteenth and Twentieth Centuries', in: Dirk Hoerder / Amarjit Kaur (eds.), Proletarian and Gendered Mass Migrations: A Global Perspective on Continuities and Discontinuities from the 19th to the 21st Century, Leiden 2013 (forthcoming).

${ }^{10}$ To name only a few titles: Donna R. Gabaccia, Immigrant Women in the United States: A Selectively Annotated Multidisciplinary Bibliography, Westport 1989; id., From the Other Side: Women, Gender and Immigrant Life in the U.S. 1820-1990, Bloomington 1994; id. / Franca Iacovetta (eds.), Women, Gender, and Transnational Lives. Italian Workers of the World, Toronto 2002; Rita J. Simon / Caroline B. Brettell, International Migration: The Female Experience, Totowa 1986. 
nouncements of a "feminization of migration." However, what has changed is that in present-day caregiver and domestics migrations women leave first, are often married, leave children behind, and as personnel in middle-class homes - rather than being restricted to ethnic working-class quarters - they are highly visible because of color of skin. Increasingly women are the major breadwinners for their families. ${ }^{11}$

Thus migration research, in becoming global, has questioned its gender and racial implications.

\section{Migration Systems: Transnational or Translocal- Transregional-Transcultural}

In common parlance, data collection, and much of research, migrants move between states: Poles to Germany, Indians to Britain, Chinese to Indonesia. However, both aggregated and disaggregated empirical data point to different socio-geographic scales of analysis: macro-regional migration systems and micro-regional, yet longdistance, migrant networks. The five major 19th-century migration systems comprised the Atlantic economies, the Chinese Southeast Asian diaspora, the plantation belt, the Russo-Siberian one, and north-China-to-Manchuria one, as well as many smaller others; late 20th-century migrations involve the oil-producing countries, Europe's so-called guest-worker system, Africa's sub-Saharan region, and numerous others, large, mid-sized, or small. Parallel to these macro-regional systems, each and every migrant man or woman connected and connects a locality of origin and a locality of destination. Migrants target specific local labor markets since they have to find an income-generating job immediately; they keep contacts and retain emotional ties with the family and community they have left behind, and not with some state or society as a whole. The state-

${ }^{11}$ Christiane Harzig, 'Women migrants as global and local agents: new research strategies on gender and migration', in: Pamela Sharpe (ed.), Women, Gender and Labour Migration. Historical and Global Perspectives, London 2001, pp. 15-28. 
Dirk Hoerder

centered approach has relevance as to exit regulations (if any) and, more importantly, as to entry barriers. Economic policies and private capitalist development also frame the need to depart from societies in which sustainable lives are not possible, or they attract potential migrants by providing options for life projects.

The state- or nation-centered approach received a new impetus in the early 1990s, when anthropologists took note of the cultural continuities that migrants establish across borders and conceptualized "transnational" ties. This term was quickly adopted by researchers and became almost a catchword. ${ }^{12}$ The "trans" correctly emphasizes the continuities in migrants' lives and critiques the dividing aspects of political borders - it thus fits well with the reconceptualization of borders and borderlands. But the "national" misrepresents the internal differentiation of nations and states. From a stateside perspective, women leaving the Philippines for caregiving work in Canada do carry Philippine passports and have to meet Canada's entry requirements, but they have been socialized in a particular place, a metropolis like Manila or some city, town, or village on another, smaller island. They also do not arrive in some construct of a generic Canada, but acculturate in a neighborhood of Toronto, of a prairie town, or other. In Toronto they would find a community of earlier arrivals from their culture, in a northern Saskatchewan community they would be without community support. The connection between place/community (space) of departure and space of arrival thus is translocal and, since local places are shaped by their immediate socio-economic environments, transregional. Given present mobility, connections may involve multiple spaces, several sequential places of arrival, as well as spaces where migrating friends live. In view of options in labor markets across the globe, "glocal" connectivity is a useful conceptualization. Research

\footnotetext{
${ }^{12}$ Steven Vertovec, 'Conceiving and researching transnationalism', Ethnic and Racial Studies, 22 (1999), 2, pp. 447-462.
} 
thus requires specific transcultural analyses rather than generalized structural and often constructed transnational/trans-state frames. ${ }^{13}$

On the macro-level, migration systems connect two or more distinct societies, each characterized by degree of industrialization and urbanization, by political structures and current policies, by specific educational, value, and belief systems, by ethnic composition and demographic factors (age structure, marriage patterns, dependency ratio), and by traditions of internal, medium-distance, and long-distance migrations. Migration systems involve clustered moves that continue over time (as distinct from non-clustered multidirectional migrations). Gross and net quantity of migration flows, continuity over time, and the ratio per 1,000 persons can be measured on this level; general push-and-pull-factors and state-wide admission regulations may be analyzed. But for individual migrants, such data provide no more than the frame for making their lifecourse decision. ${ }^{14}$

${ }^{13}$ Dirk Hoerder, 'Transnational - transregional - translocal: transcultural', in: Carlos Vargas-Silva (ed.), Handbook of Research Methods in Migration, Cheltenham 2012, pp. 69-91.

${ }^{14}$ The concept of spatial "migration systems" and the comprehensive economic-social-cultural "systems approach" to factors inducing migration decisions has been developed by many scholars globally. Selected references by year of publication: J. J. Mangolam and H. K. Schwarzweller, 'General Theory in the Study of Migration: Current Needs and Difficulties', International Migration Review 3 (1968), pp. 3-18; A. L. Mabogunje, 'Systems Approach to a Theory of Rural-Urban Migration', Geographical Analysis, 2 (1970), 1, pp. 1-18; M. P. Todaro, Internal Migration in Developing Countries: A Review of Theory, Evidence, Methodology and Research Priorities, Geneva 1976; James T. Fawcett and Fred Arnold, 'Explaining Diversity: Asian and Pacific Immigration Systems', in: James T. Fawcett / Benjamin V. Cariño (eds.), Pacific Bridges: The New Immigration from Asia and the Pacific Is lands, Staten Island 1987, pp. 453-473; James H. Jackson, Jr. / Leslie P. Moch, 'Mi gration and the Social History of Modern Europe', Historical Methods, 22 (1989), pp. 27-36; Ronald Skeldon, Population Mobility in Developing Countries: A Reinterpretation, New York 1990, pp. 27-46; Mary M. Kritz / Lin L. Lim / Hania Zlotnik (eds.), International Migration Systems: A Global Approach, Oxford 1992, pp. 1-16; Mike Parnwell, Population Movements and the Third World, London 1993. 
Dirk Hoerder

Transculturation is the process in which individuals and societies change themselves by integrating (often, at first, only some aspects of) diverse cultural ways of life into dynamic new ones. Transcultural history, present societies, and individual lives imply that people, ideas, and institutions do not have clearly defined and bordered national identities. Rather, people and societies transport, transpose, translate, and assemble aspects of different cultures. Culture is not distinctively Chinese or Algerian or other but aspects of it began/begin and ended/end somewhere else. Transcultural practices involve spoken and body language, arts and beliefs, tools and institutions. Migrants and societies create translocal and transregional transcultural spaces. Subsequent interactions and migrations will again change this new - and transitory - culture. Past research and present politics often overlook that migration whether short-distance intra-regional or long-distance global - involves transculturation of societies as a whole rather than merely adaptation by the newcomers. ${ }^{15}$

\section{Literature}

The migration historiography emerged out of ethnic group history and labor history - and, like both fields, at first did not include the agency of women. When, under the impact of analyses by Anthony D. Smith, Benedict Anderson, Eric J. Hobsbawm, and Terence Ranger, concepts of national (or ethnic) identities collapsed, studies of ethno-cultural groups, which assumed bordered identity groups, also came to a sudden end. Borderlines of cultural groups were reconceptualized as fuzzy and permeable. ${ }^{16}$ About a decade later, from the 1990s, new studies on transborder, transnational, and transcul-

\footnotetext{
${ }^{15}$ Dirk Hoerder, 'Transculturalism(s): From Nation-State to Human Agency in Social Spaces and Cultural Regions', Zeitschrift für Kanada-Studien, 24 (2004), pp. 7-20.

${ }^{16}$ Robin Cohen, 'Fuzzy Frontiers of Identity: the British Case', Social Identities, 1 (1995), pp. 35-62; id., 'Rethinking 'Babylon': Iconoclastic Conceptions of the Diasporic Experience', New Community, 21 (1995), pp. 5-18.
} 
tural exchanges and métissage, fusion, and hybridity emerged. Of the latter, some followed a cultural studies jargon (like "The Slave Business: Notes on a Hermeneutics of Absence and a Pedagogy of the Trace", on a place with no slaves); most provided thoughtful and empirically researched analyses of braided and entwined cultures emerging in processes of spatial mixing and interaction. More recent ones achieve this on a global scale, for example on Somali and Philippine domestic workers in Rome. ${ }^{17}$

This short survey will focus on studies of migration rather than of acculturation and métissage. ${ }^{18}$ Labor historians, like ethnic and national(ist) historians constrained by their socialization in the frame of one state, focused on labor organizations and strikes, then on the working classes, and finally on working class culture and working women. While Marxist historians assumed an internationally-minded proletariat with - in a simplified version - nothing to lose but its chains, ethnic historians pointed out that workers also have a culture to lose. An early compilation of sources on immigrant workers in the US and Canadian labor movements, however, noted that workers expressed themselves in their respective national cultural frames of reference even when conditions of exploitation were similar, and thus were internationally mobile but not internationally minded. ${ }^{19}$ This was not new: the Austrian socialists, Otto Bauer and Victor Adler in particular, had come to differentiated as-

${ }^{17}$ Victoria Chell, 'Gender-Selective Migration: Somalian and Filipina Women in Rome', in: Russell King / Richard Black (eds.), Southern Europe and the New Immigrations, Brighton 1997, pp. 75-92.

${ }^{18}$ An early differentiated conceptualization of immigrant acculturation emerged - like much of the scholarship on many-cultured and multicultural societies - in Canada. John Goldlust / Anthony H. Richmond, 'A Multivariate Model of Immig rant Adaptation', International Migration Review, 8 (1974), pp. 193-225. For a differentiated concept of transnationalism see Thomas Faist, The Volume and Dynamics of International Migration and Transnational Social Spaces, Oxford 2000.

${ }^{19}$ Dirk Hoerder, 'An Internationally Mobile Working Class and Its Press in North America: A Survey', in: id. / Christiane Harzig (eds.), The Immigrant Labor Press in North America, 1840s-1970s. An Annotated Bibliography (3 vols.), Westport 1987, vol. 1, pp. 1-47. 
Dirk Hoerder

sessments of cultural specifics, the "Nationalitätenfrage," around 1900. When decolonization was being turned by capitalist neo-colonialism into a global zone of "cheap labor" countries, the tension between cultural specifics and cross-cultural class aspects was reassessed: race, rather than ethnicity, was the marker of a new "global apartheid," to use the term introduced by Canadian sociologist Anthony Richmond. Class and race motivate migration out of constraining circumstances. ${ }^{20}$

In the late 1980s and early 1990s several early summaries of worldwide labor migrations appeared, emphasizing issues of race and global power relations as well as class over ethnicity. ${ }^{21}$ Subsequent studies dealt either with particular migratory movements, for example of Mexican or West African workers to more developed societies, i.e. societies providing jobs and better wages, albeit in the context of higher costs of living and racializing marginalization. To some degree, such migrations perpetuate but also subvert former colonial relationships. Labor migrants can use their human capital best if they target a country whose language they speak. Thus much of the migration from (formerly) French-language West and North Africa is directed to France, or from Haiti to Quebec. Such migrants remain exploitable but reverse racial segregation. Increasingly, scholars - often outside of the knowledge production of the Atlantic World - studied rural-urban migrations into labor markets for unskilled workers within Africa, Latin America, and Asia rather than falling victim to the assumption that all migration is to highly developed countries. All studies accept the skilled/unskilled dichotomy of labor. However, migrants were

\footnotetext{
${ }^{20}$ Anthony Richmond, Global Apartheid: Refugees, Racism and the New World Order, Toronto 1994.

${ }^{21}$ Robin Cohen, The New Helots: Migrants in the International Division of Labour, Aldershot 1987; Lydia Potts, Weltmarkt für Arbeitskraft. Von der Kolonisation Amerikas bis zu den Migrationen der Gegenwart, Hamburg 1988 (English translation: The World Labour Market. A History of Migration, London 1990); Nigel Harris, The New Untouchables: Immigration and the New World Worker, London 1995.
} 
skilled agriculturalists or small-town artisans before their departure. At the destinations, they usually enter construction work or assembly-line production. For them migration involves a deskilling not reflected in the accepted juxtaposition of skilled and unskilled.

From the mid-1990s, several scholars began to deal with global migrations as a whole or to fill gaps by studying macro-regions neglected in research. Robin Cohen edited a compendium of different types of migration across the world; I published a synopsis of global migration in the last millennium. ${ }^{22}$ This dismantling of the primacy of the Atlantic World's migrations and the projection of mobility back into the past have led to several new developments. Historians of the Middle Ages are now re-writing the history of territories and rulers as one of cultural exchange and migration. ${ }^{23}$ This reconceptualization is also emerging for other parts of the world and has been extended further into the past by noting that the "Völkerwanderungen" were not migrations of culturally coherent groups but involved the mobility of peoples continuously constituting and reconstituting themselves. ${ }^{24}$ Much of ancient history is also being re-written in terms of migration, acculturation, and interaction. For the present, new quantitative studies - with emphasis on Latin America and China - have been pioneered by José Moya

\footnotetext{
${ }^{22}$ Robin Cohen (ed.), The Cambridge Survey of World Migration, Cambridge 1995; Dirk Hoerder, Cultures in Contact: World Migrations in the Second Millennium, Durham 2002. See also Donna Gabaccia / Dirk Hoerder (eds.), Connecting Seas and Connected Ocean Rims: Indian, Atlantic, and Pacific Oceans and China Seas Migrations from the 1830 s to the 1930s, Studies in Global Social History, vol. 8 (edited by Marcel van der Linden), Leiden 2011; Dirk Hoerder / Nora Faires (eds.), Migrants and Migration in Modern North America: Cross-Border Lives, Labor Markets, and Politics, Durham 2011.

${ }^{23}$ Michael Borgolte, 'Migrationen als transkulturelle Verflechtungen im mittelalterlichen Europa. Ein neuer Pflug für alte Forschungsfelder', Historische Zeitschrift, 289 (2009), pp. 261-285; Michael Borgolte / Matthias M. Tischler (eds.), Transkulturelle Verflechtungen im mittelalterlichen Jahrtausend. Europa, Ostasien, Afrika, Darmstadt 2012.

${ }^{24}$ Walter Pohl (ed.), Strategies of Distinction. The Construction of Ethnic Communities, 300-800, Leiden 1998; id., Die Völkerwanderung. Eroberung und Integration, Stuttgart 2002.
} 
Dirk Hoerder

and Adam McKeown. ${ }^{25}$ A comprehensive encyclopedia of the state of the field is the forthcoming Encyclopedia of Global Human Migration, ${ }^{26}$ and the global migration approach has been extended back in time to the emergence of humankind in East Africa by Patrick Manning. ${ }^{27}$

As regards present-day labor migrations, the entry of women into academia and feminist scholarship have resulted in wideranging research on women in past migrations and on women's migrations from decolonized societies into the domestic work and caregiving sectors of societies in which families can afford lowwage migrant labor, but in which no local personnel is available for such poorly paid, yet demanding jobs. Academic pursuits remain heavily gendered - almost all studies on women's migration are undertaken by women while most men continue to focus on men's labor migrations. Some of these studies are global in dimension, ${ }^{28}$ others deal with macro-regions like Latin America or Filipinas in the world; ${ }^{29}$ more - too numerous to list - deal with particular regions of origin, Bangladesh for example, or specific destinations such as Hong Kong, Singapore, or the oil-producing economies of the Gulf of Hormuz. The studies do not only add women to the research agenda and introduce the neglected field of social repro-

${ }^{25}$ José C. Moya, 'A Continent of Immigrants: Postcolonial Shifts in the Western Hemisphere', Hispanic American Historical Review, 86 (2006), 1, pp. 1-28; Moya and Adam McKeown, 'World Migration in the Long Twentieth Century', in: Michael Adas (ed.), Essays on Twentieth-Century History, Philadelphia 2010, pp. 952; Adam M. McKeown, Chinese Migrant Networks and Cultural Change: Peru, Chicago and Hawaii, 1900-1936, Chicago 2001; id., 'Global Migration, 1846-1940', Journal of World History, 15 (2005), 2, pp. 155-189; id., 'Chinese Emigration in Global Context, 1850-1940’, Journal of Global History, 5 (2010), pp. 1-30.

${ }^{26}$ Edited by Immanuel Ness, 5 vols., forthcoming spring 2013.

${ }^{27}$ Patrick Manning, Migration in World History, New York 2005.

${ }^{28}$ Bridget Anderson, Doing the Dirty Work? The Global Politics of Domestic Labour, London 2000.

${ }^{29}$ Elsa M. Chaney / Mary Garcia Castro (eds.), Muchachas No More: Household Workers in Latin America and the Caribbean, Philadelphia 1989; Rhacel Salazar Parreñas, Servants of Globalization. Women, Migration, and Domestic Work, Stanford 2001. 
Migration Research in Global Perspective: Recent Developments

duction; they also raise questions that require the reconceptualization of unquestioned assumptions. If building a house, masonry and carpentry, is skilled labor, why is the raising of a child unskilled work? If many societies considered and consider mothers the prime agents of the inculcation of national values into infants and children, how does this change when the prime caregivers are migrant women of a different culture, color of skin, and language? If such migrant caregivers work in the supposedly "private" sphere of homes, how can public-private dichotomies and nation-vs.-ethnic ghetto clichés be revised?

These topics and the literature cited reflect only a glimpse of the vast amount of literature on migration. Forced labor - a topic of Marcel van der Linden -, migration within India or Indonesia for example, and many other issues require attention.

\section{New Migrations: Research Needs in View of Global Shifts of Economic Power and Banker-Induced Crises}

An assessment of an agenda of migration studies may begin from several different vantage points. Event history could emphasize the 9/11 (2001) terrorist destruction of New York's World Trade Center towers, which killed 3,000 individual men and women, and the "9/11" (2008) self-destruction of the towering Western financial system based on derivative junk, which, according to 2009 ILO data, caused some 18 million men and women to lose their jobs and some 200 million in developing countries to be pushed from vulnerable into unsustainable lives. ${ }^{30}$ Crises may slow down actual migration because those further impoverished lack the transaction costs for a move. But crises may also accelerate migrations: those

\footnotetext{
${ }^{30}$ International Labour Organization, Global Employment Trends, Geneva 2009, [http://www.ilo.org/wcmsp5/groups/public/---dgreports/---dcomm/docume nts/publication/wcms_101461.pdf]; The Guardian, 19 August 2010, summarized an Oxfam 2010 Report as "Poor Nations pay for bankers' greed."
} 
Dirk Hoerder

with no options cross the Mediterranean into fortress Europe, or the US's new iron curtain on its southern border, or other "impediments," to reach societies which (seem to) provide some options for survival. In Western thinking, it is acceptable that investors migrate to China to achieve higher returns on their capital, but it is not acceptable that common people migrate to "richer" countries to achieve better returns on their human capital.

A process-approach would analyze the changing impact of globalization. Often said to be recent, globalization is in fact a development that dates at least from the 15th century: (1) a new level of global capitalism and financial institutions which, in a frame of global apartheid, have destabilizing - i.e. for potential migrants literally unsettling - effects in low-income countries; (2) technological change that reduces the cost and time of long-distance transport; (3) worldwide political transformations such as de- and recolonization; (4) the universalization of human rights, which challenges the inferiorization of minorities and migrants; (5) a rise of expectations among people in countries with low standards of living who, via TV and YouTube, literally live "in view" of wealthy segments of the world; (6) changing global economic power relations that juxtapose fast developing societies such as China, India, Brazil, and Russia with regimes that institutionalize high levels of inequality, such as Mexico and India.

In such complexities, the nation-state gatekeepers' postulated mono-cultural and essentialized national identities have little impact on the myriad of decisions to migrate. As in the past, migration appears as a counter-narrative to the nation; mobile life trajectories and multi-locality counter the bordered territoriality of unsatisfactory and unsafe - home? - states and unsustainable lives in them. ${ }^{31} \mathrm{~A}$ comprehensive analysis discerns an ongoing, deepening global crisis: in the mid-1990s, the gap between the wealthiest and the poorest countries of the globe, compared to 1960, had

\footnotetext{
${ }^{31}$ See, for example, Luis E. Guarnizo / Michael P. Smith (eds.), Transnationalism from Below, New Brunswick 1998.
} 
Migration Research in Global Perspective: Recent Developments

doubled: the richest 20 percent of the world's population were almost 60 times better off than the poorest 20 percent - and the chasm continues to grow. ${ }^{32}$ In the decades after World War Two and decolonization, globalized Western capital imposed unequal terms of trade on (non-white) less developed and poorer countries, and intellectual gatekeepers like Bernard Lewis and Samuel Huntington, as well as parts of the mass media, replaced the Cold War's systemic antagonism - a "free West" vs. a communist "bloc" - with a new, color-of-skin-coded antagonism: a Christian vs. an Islamic world. Such ideologues, too monocultural to deal with diversity and multiple options, develop a new politics of identity. Is "Western" identity so brittle, so vague, or so undefinable that a devilish alien Other - once witches and heretics, then communism, now multiculturalism, Mexicans, and Muslims - is needed to keep it from coming apart? Is an outside enemy the straitjacket that holds together societies, rather than internal achievement? ${ }^{33}$

Much of the present migration - rather than from the Global South to the Global North - is taking place within the fast growing economies of Brazil, Russia, India, and China. In the course of mass migrations from marginal regions to production sites in China alone, some 200 million rural men and women have moved to cities where, however, they are usually not accorded residence rights. ${ }^{34}$ As with European designations such as "vagrants" or "itinerants," Chinese society's hostility to migrants is reflected in the naming: migrants are a "floating population." Parallel to the BRIC economies' migrations to jobs, "deindustrialization"-migrations

\footnotetext{
${ }^{32}$ Hoerder, Cultures in Contact (as cited in note 22), p. 516.

${ }^{33}$ This argument is developed further in Hoerder, 'Transformations over Time or Sudden Change: Historical Perspectives on Mass Migrations and Human Lives', published in German as: 'Allmähliche Transformation oder plötzlicher Wandel: Historische Betrachtungen zu Massenmigrationen und Menschenleben', Comparative Population Studies. Zeitschrift für Bevölkerungswissenschaft, [www.comparativepopulationstudies.de].

${ }^{34}$ Migrations in the next 20 years will involve a further 350 million, according to estimates.
} 
Dirk Hoerder

occur from, for example, the US "rust belt" and Detroit's automobile factories.

While migration studies have focused, for good reasons, on mass migration, a vast array of small-scale moves indicate new patterns and demand a new research agenda, perhaps even a basic change of perspective. Contrary to the media's and public opinion's focus on the poor of the world "inundating" (allegedly) wealthy Western societies, many specialists are already reversing their direction of inquiry and leaving the stagnating "West" for dynamic "BRIC" and other societies. Unexpectedly, in-migration to "the West" from "developing" countries involves highly qualified experts, because (underfunded) "Western education" fails to supply them. The most-cited case in point is that of software programmers migrating (often within the structures of global companies) from India to the Netherlands, the US, and other "highly developed" economies.

While the Western press dealt with migrants as "problems" in the decades from the 1950s to the 1980s and 1990s, a new awareness of migration has induced regular and differentiated reporting. ${ }^{35}$ Whole sections of newspapers are devoted to "Europeans who leave," "French without borders," and the "planet-wide nomadism of students." Emigration from wealthy but stagnating countries to richer societies in Asia and elsewhere includes, for example, some 1.5 to 2.5 million French: art gallery owners, luxury hotel managers, sommeliers, and young people with degrees but no options. Wealthy Chinese and Russians recruit English butlers and French

${ }^{35}$ The following is based on a mere six-month period, January to June 2012, of reporting in Le Monde, Le Monde diplomatique, and Courrier international. It could be expanded by a reading of the British Guardian, The Canadian Globe and Mail, the international capitalist Financial Times and newspapers in Algeria, Lebanon and Nigeria. Interestingly, the US press continues its "provincializing" of the US and hardly reports on global migrations.

The topic has achieved prominence to a degree that TV or video programs in several countries, Australia and Germany for example, as well as a large number of films, French co-productions in particular, deal with migration, including undocumented migrants and refugees, and acculturation-interaction after arrival. 
wine experts. ${ }^{36}$ Japan recruits highly qualified technicians to develop a new generation of automobiles; Uruguay recruits experts in many sectors. US Americans - once told: "go west, young men" now migrate east, with China as their destination. Press concentration in Western countries forces journalists to leave. University and technical school graduates leave Greece, Portugal, and Spain. Portugal - with the lowest level of schooling in the EU - encourages teachers, whom the state is unable to pay, to emigrate. Young Turkish-German men and women migrate to Turkey, where options for jobs and careers are better. Chinese immigrant small businesspeople depart the Greek economy. Russians with qualifications go to wherever in the world jobs are available - no previous migration paths channel them to communities of earlier migrants. Canada's and England's universities have to recruit fee-paying students from Asian societies. Young experts move from stagnant former colonizer societies to the dynamic economies of the former colonies/dependent economies: Portuguese experts move to Angola and Brazil, and Spanish experts to Brazil.

While India's institutions of higher education produce more specialists than the country's labor market can accommodate, other developing countries lose needed qualified personnel in brain and skill drains: (poorer) societies invest in the young generation's education and training, and other (richer) ones benefit from their skills and taxes. The Philippines face a shortage of doctors and nurses; the countries of the Maghreb lose their best-qualified young people to countries like France. Destinations provide jobs and better pay, but migration does also involve a critique of societies' structures: the selected destinations also offer options for life projects not restrained by hierarchical or fundamentalist social organization.

A different category of migration is that of wealthy persons, who move their assets away from the societies in which they accumulated them. Wealthy Greek buy real estate in Berlin and other

\footnotetext{
${ }^{36}$ In Japan, even a manga on wine and sommeliers has made its appearance: Shin Kibayashi / Yuko Kibayashi, Kami No Shizuku [“The Drops Of God”], 2004 ff.
} 
Dirk Hoerder

capital cities, newly wealthy Bulgarians move to Vienna, Brazilians to Lisbon, Chinese from the PRC to Canada, and, recently, wealthy French to London and Switzerland, following the victory of the Socialist Party in the presidential election of June 2012. Within cities of both old industrialized and new BRIC countries, segments of the wealthy move from "open society" into enclosed, "gated" communities, thus increasing internal segmentation and segregation.

Labor migrations continue, but rather than coalescing into major migration systems, they have become highly diverse. In addition to technical personnel, unskilled workers are needed at often isolated sites of raw material extraction - northern Alberta oil sands, southern Patagonia oil drilling, Kazakhstan, mining sites in Africa. Workers for the three-D sector - dirty, dangerous, demeaning jobs - are moving from Senegal to France, from Taiwan to mainland China, from Somalia and Mexico to Minnesota chicken and meat factories. A new market for military labor - mercenaries is developing: Africans for the US army and private war contractors, Nepalese Gurkhas for the British army. In the worst cases, traffickers circumvent the exclusionary entry regimes of labor-importing states and channel men and women without documents into narrow segments of the labor market, where they remain bound to the traffickers until they pay off the high debts incurred. This sector includes the trafficking of women into sex labor against their will. A related market for women's bodies and emotions has developed in countries with selective abortion of female fetuses and resulting unbalanced sex ratios in the population. China and India import women; Myanmar women are sold into this trading system.

The largest labor migrations remain those from deprived rural areas in the BRIC countries - similar to those in the Asian "tiger economies" from the 1960 s to the 1980 s and across the Atlantic from the 1880 s to 1914 - to urban agglomerations and sites of mass production with miserable living conditions, such as for example the bidonvilles of Mumbai/Bombay or the favelas of Rio de Janeiro. By contrast, in African countries wracked by warlordism, like 
Somalia, or factional fighting, like Nigeria, large numbers of refugees are stacked away in camps and prevented from migrating. Multi-generational camp life was first imposed on Palestinians by Israel, then on "minority" peoples by right-wing, US-supported regimes in Central America - the infamous "banana republics." Such camps, and survival on the margins, proliferate in and around Afghanistan, Syria, the Congo RDC, Nigeria, and Mali, to name only a few. Of countries involved in long wars of decolonization, Angola has become a migrant-attracting economy due to its oil wealth, while Algeria has become an emigration country due to its ossified political structures. In an increasing number of regions, refugee generation is a consequence of religious fundamentalism: people depart from regions taken over by Islamist Taliban and others, are deported from annexed territories by Jewish ultra-orthodox settlers, leave the US bible belt because of constraints on personal choice. The fundamentalists of the world have united. ${ }^{37}$

Given the ever deepening global wealth gap, populations in segments of the world with high standards of living and their state apparatuses are contributing to hunger - a push factor for migration in poorer segments. The EU's fishing fleets engage in mass "harvesting” of fish and shrimp off West Africa's, Madagascar's, and India's coasts, depriving local populations of food and jobs. Garments for sale in the EU and US are produced, for example, at Thailand's western border by undocumented migrant women workers from Myanmar. They cannot feed their children from the wages paid but know how exquisitely Western consumers dress. While such production is organized by global capitalist conglomerates and local capitalist subcontractors, such migration-inducing exploitation cannot simply be blamed on an abstract "capitalist system": the consumers have faces - usually white ones - and live mostly in high-income societies. Occasionally, migrant workers' faces also become visible: in February of

\footnotetext{
${ }^{37}$ In addition, in several states across the globe religious and ethno-cultural minorities are targeted by repressive measures: the numerous non-Burmese peoples in $\mathrm{My}$ anmar under military rule, recently Copts in Egypt and non-Magyars in Hungary.
} 
Dirk Hoerder

2004, undocumented Chinese cockle pickers working in England, for a subcontractor of major British food chains, were overtaken by the tide and 23 drowned. A documentary video recounts the life of Ai Qin, a young Chinese woman, who paid human smugglers 25,000 US dollars to get to Britain. Her goal was to earn enough money to provide food and education for her son. Rice - a major staple in China - and basic foods elsewhere have become financial products in futures trading and commodity speculation. People with low incomes can no longer feed themselves. ${ }^{38}$ Research needs to combine global economic structures with specific worldwide migrations in translocal, transregional, and trans-state contexts.

Though migrants are essential for the economic and social functioning of (formerly?) highly developed societies, segments of the respective populations and media have developed an anti-immigrantism that resembles the past's anti-Semitism - pogroms, murder, and mass expulsions included. In the US, Mexicans are deported regardless of the political party in power; Israel's government deports Sudanese and other African immigrants without papers, a color-of-skin-based racist policy. In addition to new analyses of global capitalism, migration researchers need to reflect on the impact of the new inequalities on societies as well as on individuals' lives. ${ }^{39}$ The moral philosophy or moral economy of late 18th-century thinkers such as Adam Smith, or of 19th-century thinkers such as Karl Marx, ${ }^{40}$ provides frames of reference for global migration studies.

${ }^{38}$ BBC News, 'Morecambe Bay: one year on', [http://news.bbc.co.uk/2/hi/uk_n ews/4238209.stm]; 'Ghosts. Morecambe Bay. February 5, 2004. 23 Lives. 23 Souls', by Nick Broomfield, 2007, 96 min; 'Quand le riz devient un produit financier', Le Monde diplomatique, February 2012, p. 8.

${ }^{39}$ Richard Wilkinson / Kate Pickett, The Spirit Level: Why Greater Equality Makes Societies Stronger, London 2009; 'Rethinking Equality in an Age of Inequalities', IWM-Post (Institut für die Wissenschaft vom Menschen, Vienna), 108 (September-December 2011).

${ }^{40}$ Nicholas Phillipson, Adam Smith. An Enlightened Life, London 2010; Marcel van der Linden / Karl Heinz Roth (eds.), Über Marx hinaus: Arbeitsgeschichte und Arbeitsbegriff in der Konfrontation mit den globalen Arbeitsverhältnissen des 21. Jahrhunderts, Berlin / Hamburg 2009. 